\title{
Development of Materials Are Based on Character Values to Improve Intensive Reading Skill Students for Class III in Elementary School
}

\author{
Cicilia Clara Devi Anggraini*; Tri Murwaningsih; RetnoWinarni \\ University of Sebelas Maret Surakarta, Indonesia \\ Email: ciciliaclaradevianggraeni@gmail.com
}

http://dx.doi.org/10.18415/ijmmu.v5i2.131

\begin{abstract}
This research aims to develop learning material is insight of a fairy tale that containing character values for grade 3 students through a handbook, consisting of teacher books and student books that can improve students' intensive reading skills. This fairy tale material involves learning fairy tales with character-oriented insights and guided by using the correct intensive reading skill steps and easy to learn, understand, and understood by the students. This instructional material is equipped with competency map to be achieved by the students, description of student learning materials, student learning activities, exercise questions, reflection, and assessment used to measure students 'competence to the students' intensive reading skill. Research method in this development is using Borg and Gall technique. Expert validation results show content-oriented teaching materials to improve students' intensive reading skills that are valid and highly viable to use. Students' responses to the understanding of character values are increasing. Teaching materials based on character values to enhance intensive reading skills can improve the intensive reading skill of students' fairy tales. The results of this study indicate that there is a significant difference between post test of experimental group and control group. Mean experimental group postest 83.6 and average control group postestscore of 78, both groups had a difference of 5.6, indicating a significant increase in increment. So it can be said that the experimental group of learning by using old teaching materials plus storytelling materials with character values insight to improve intensive reading skills more effectively improve student learning outcomes.
\end{abstract}

Keywords: Teaching materials; Fairy tale; Character values; Intensive reading skills

\section{Introduction}

Fairy tale is a story that contains about the fantasies of children's stories that contain the values of characters taken from the fairy tale. According to (Ibnoe., 2016, p.13), "Storytelling is one of the most excellent methods to improve children's intelligence." To improve the child's intelligence, the element of intensive reading skill is very important to be considered for the development of teaching materials of fairy tales. This opinion is supported by the research (Febriani., 2012, p.2) says that "Fairy tale is used as a method to obtain information which is the cultural richness of this nation, before the era of people know writing, the fairy tale is a medium of social values that are noble by parents and ancestors to future generations." 
Indonesian languange is one of the subjects in Elementary School that has a wider scope. The scope of Indonesian subjects includes the components of language skills and literacy skills that include several aspects that are often referred to as SC (Standards Competence) namely SC listening, SC speaking, reading SC, and writing SC. SC Indonesian language course is a minimum ability qualification of students who describe the mastery of knowledge, language skills, and a positive attitude to Indonesian language and literature. The basic competencies are taught gradually and continuously so that students have good and communicative language skills.

Indonesian language learning in EULC (Education Unit Level Curriculum) is directed as a means of developing language skills that make students self-sufficient throughout life, creative, and able to solve problems with skilled Indonesian language. Indonesian language skills that students have not yet reached as directed in the EULC. It is in reality visible when students have the intensive reading skills required in fairy tale material. This is reinforced by the research development that has been done by (Mardiah, et al, 2016., p.1115) says that reading is a process of someone in reconstructing a message.

Intensive reading skills as one aspect of language skills must be mastered and owned by students. This is in line with that put forward by (Dalman., 2014, p.5) says that reading is an activity or cognitive process that seeks to find information. In addition, according to (Tarigan., 2008, p, 36), "Intensive reading is a careful study, meticulous study, and detailed handling conducted in the classroom on a short task of about two to four pages per day." Intensive reading skill is meant in the low grade that is in class III Elementary School.

According to (Mustari., 2014, p, 8), "Character values are character education efforts that can improve the quality of current and future generations." The character values developed in the development of teaching materials of fairy tales to develop intensive reading skills as supporting data have been measured by using indicators in 10 character values ie religious character indicator, honest, discipline, hard work, independent, creative, friendly/communicative, peaceful, caring, and responsible. In addition, according to (Asma., 2014, P. 72), "Character values are religious values, social norms, rules or laws, academic ethics, and human rights principles, grouped into five main values, that is, the values of human behavior with God Almighty, self, fellow human, environment, and nationality."

So, it is very important to implement the values of the characters in learning one of them through the development of teaching materials fairy tale insight character values. This is reinforced by research development that has been done by (Ulum., 2014, p.131) said that the education of personality/important character implemented to equip learners independent life.

Referring to the description of the experts above, the character values is one of the right solutions to improve the intensive reading skills of third grade students of elementary school on fairy tale material. Because in the development of teaching materials fairy tale stories containing character values that can be taken from the wisdom of behavior that is told through the characters contained in it to improve one intensive reading skills in learning Indonesian in elementary school. This is supported by the development research that has been done by (Febriani., 2012, p.2) said that the planting of character values can be done through communication effort, the reading of fairy tale is one effort that can be done to establish communication, understanding and the planting of character values through the fairy tale will give more impression that will be easy to be applied by students in everyday life.

The teaching materials in this lesson have advantages as the students really understand the subject matter and all students are happy, enthusiastic, and actively involved in the learning activities so as to provide immediate experience for the students. 


\subsection{Research Problem}

Practices that occur in the field, learning that took place in Purwodadi Sub-District of GroboganRegency found a little story-tale teaching material that are weighted for students and teachers in each level of educational unit, because the location leads to lack of human resources and professional teachers in making a the work of teaching materials, especially the teaching materials of fairy tale insight of character values. Facilities and infrastructure are Minimum available. In addition, learning activities that advocate the use of information technology as a teaching medium are still rarely used. Students who attend school on average come from middle to lower family.

The result of the observation when the teacher taught, found the teacher was using the teaching materials with the appropriate approach of teaching teacher, which is delivering the material with more lecture and giving the task contained in LKS. The learning process is dominated by the teacher by explaining the material. Students are less involved in activities intensive reading skill so that impressed students do not understand the contents of fairy tales. It makes students bored, even some are sleepy and passive.

Based on this research, the development model is not applied as a whole. However, the steps change into three stages. The first stage is a preliminary study; this stage consists of three stages, namely literature study, field survey, and preparation of the initial product. The second stage is the development of a model consisting of two stages, namely a limited trial and a wider trial. The third resistance is the model test at this stage is the effectiveness of the experimental product produced by using the experimental method (Sukmadinata., 2012, p.184-187).

Development stage and initial product validation of teaching materials for fairy tales with characteristic values is to improve intensive reading skill in Elementary School in Purwodadi Sub-district of GroboganRegency. The limited trial phase will be conducted in SD Negeri 16 Purwodadi by way of sample is 10 students. While the field trial/trials will be conducted in two elementary schools in Purwodadi sub-district of Grobogan Regency, SD Negeri 1 Danyang and SD Negeri 4 Purwodadi. For the experimental class conducted in SD Negeri 2 Danyang and control class is done in SD Negeri 3 Purwodadi.

\section{Literature Review}

\subsection{What Is Teaching Material?}

According to (Daryanto., 2014, p.171), "Teaching materials are all forms of materials used to assist teachers/instructors in carrying out teaching and learning activities in the classroom, the material can be either written or unwritten material." Therefore, teaching materials are made to foster learning that is interesting, effective, and efficient.

\subsection{What Is a Fairy Tale?}

According to (Ibnoe., 2016, p.13), "Storytelling is one of the most excellent methods to improve children's intelligence." The material that is in this fairy tale is developed with insight of character values. This opinion is supported by research (Febriani., 2012, p.2) which says that "Fairy tale is a story that is used as a method to obtain information which is the cultural wealth of this nation, before the era of people know writing, the tale is a medium of social values which the parents and the ancestors have brought to the next generation." 


\subsection{What Are Character Values?}

According to (Samani and Haryanto., 2012, p.17), "Character is defined as a way of thinking and behaving that is peculiar to each individual to live and work together, whether in the family, society, nation and state." This means that every individual who is a good character is an individual who can make decisions and ready to account for any consequences of his decision.

This opinion is supported by opinion (Asma., 2014, p.72), "Character values are religious values, social norms, rules or laws, academic ethics, and human rights principles, grouped into five main values, man with God Almighty, self, fellow human, environment, and nationality."

\subsection{What is Intensive Reading Skill?}

According to (Dalman., 2014, p.71) "Intensive reading essentially requires a text of no more than 500 words (which can be read in a 2 -minute period at a rate of about 5 words in a second)."

This is in agreement with (Tarigan., 2008, p.36), "Intensive reading is a careful study, meticulous study, and detailed handling done in the classroom against a short tough task of approximately two to four pages per day." In this development indicator of intensive reading skill which is light and simple adjusted by requirement of third grade student of elementary school that is (1) know fairy tale character; (2) recognize the story of fairy tales; (3) understanding the content of fairy tales; (4) find the moral message of character values in fairy tales; (5) the ability to find the core/contents in every paragraph of fairy tale; (6) the ability to find conformity with the original cheerfulness; (7) the ability to find themes/topics of fairy tales; and (8) the ability to infer the content of fairy tales.

\section{Design, Sampling and Methodology}

The development and the object of research produce the teaching material of the product, but also lead to the effort of formulation of learning technique until ready to be used as product model of teaching materials that can be applied to teacher and student in fairy tale learning.

Based on teaching materials consist of 2 books, special teacher book (TB) and student book (SB). The teacher's book is packaged for the work of teachers in fairy tale learning, while the student's book is packed as a supplement book or book on fairy tale learning. The preparation of these instructional products, based on needs analysis, through a systematic trial process in the field, is carefully observed, discussed with experts and stakeholders, revised until the final product is a new resource product.

Primary schools located in Purwodadi District of GroboganRegency is used for research have similarities in curriculum, accreditation, and average score. Curriculum used from SD Negeri 16 Purwodadi Curriculum, SD Negeri 1 Danyang, SD Negeri 4 Purwodadi, SD Negeri 3 Purwodadi and SD Negeri 2 Danyang using EULC curriculum, so for accreditation is middle level and the average value of Indonesian language learning kususnya intensive reading of fairy tales is classified as medium.

Borg and Gall (2003., p 569) says that "R \& D education is an industry-based development model where research findings are used to design new products and procedures, which are then systematically tested, evaluated and refined to meet the criteria of effectiveness, quality, or the same standard." Research and development is a basic development model that is oriented to create a new product or step systematically. Where the products used in this study developed and performed validation and evaluation 
of the appropriate product will be the effectiveness in accordance with predetermined standards and quality.

The purpose of this stage is to develop prototype (initial draft) of teaching materials into teaching materials of character values to improve intensive reading comprehension of grade 3 elementary school students, which include: (1) the need of teaching materials for teachers and students; (2) preparation of initial draft (prototype); (3) development of prototype of teaching materials into teaching materials; and (4) test the effectiveness of teaching materials.

\section{Results and Discussion}

The results of the research and discussion in this study are reported in Chapter IV that are consistent with the research problem, namely: (1) the need for teaching materials needed for teachers and students; (2) preparation of initial draft (prototype); (3) development of prototype of teaching materials into teaching materials; and (4) test the effectiveness of teaching materials.

\subsection{Material Requirements for Teachers and Students}

It is known that there are teachers who do not apply the book compiled in teaching. This is due to the unavailability of learning tools that he compiled. The fact is that: (1) lack of literature as a source of teacher teaching materials; (2) teachers do not understand how the steps and techniques of writing teaching materials; (3) no correction team; and (4) the time available to write teaching materials is only 2 weeks.

\subsubsection{Teacher Response}

Based on the data analysis of the questionnaire on the teacher informant as a user of the old teaching material, it is stated that the reason for using this book is because: (a) there is no other choice, only the book is sold in the proceeds from the publisher instead of the teacher's own; (b) the price of the book according to student pockets or student abilities; (c) a book that is easily available because it is delivered directly by the marketing officer to the school; (d) the principal is advised to use the resource; (e) the teacher benefits from the sale of the teaching materials; (f) free teacher teaching materials and equipped with teaching tools, (g) their contents in accordance with EULC.

\subsubsection{Student Response}

The response of students as users of old teaching materials responds to questions raised in evaluating the feasibility and quality of old teaching materials which can be summarized as follows: (a) the material space in the teaching materials is too short and incomplete so it is rather difficult to understand, the slightest example; (b) the contents of teaching materials have not all guided or stimulated students in improving the competence of intensive reading skills. This can be seen based on the exercise that leads the students to the activity of intensive reading skill activities, and even the teaching materials that have no assessment of intensive reading skill indicators; (c) teaching material material is irrelevant to the basic competencies, needs, abilities, and environment around the student using the name of a foreign character; and (d) the approach teachers use in conveying material by teachers is more dominant to read unstructured tales freely unstructured as per indicators of intensive reading skills. 


\subsection{Teaching Material Results is Insight of Character Valuesto Improve Student Intensive Reading Skills}

According to (Daryanto., 2014, p.171), "Teaching materials are all forms of materials used to assist teachers/instructors in carrying out teaching and learning activities in the classroom, the material can be either written or unwritten material."

Based on the exposure in this research, teaching materials are made in the form of textbooks consisting of 2 books, teacher books, and student books. The teacher's book (TB) is packed for teachers in a more complete teaching than student's books. Student Handbook (SB) is packaged in student activity sheet which contains various activities of learning done by students in reading fairy tales. The teaching materials are insightful of character values to improve the intensive reading skill of grade 3 elementary school students in the teacher's books according to the material present in the student book.

\subsection{Limited Trial}

Based on the findings of limited trials, weaknesses, and excellence of teaching materials, the results of interviews with students and teachers as materials to determine the feasibility of the design of teaching materials. A limited trial was conducted at SD Negeri 16 Purwodadi by using 10 student samples. The prototype designs used in the limited trials can generally be said to be feasible for use in extensive trials. However, it needs to be revised from the findings and suggestions for improving the prototype so it is better to use extensive trials.

\subsection{Broad Trial}

This broad trial was conducted in 2 elementary schools in Purwodadi sub-district, Grobogan Regency, namely: SD Negeri 1 Danyang amounting to 30 students and SD Negeri 4 Purwodadi amounted to 34 students. The sample of students is 64 students from two classes.

The students value for intensive storytelling skills in grade III SD Negeri 1 Danyang and SD Negeri 4 Purwodadi use teaching materials with characteristic values to improve students' intensive reading skill, that the highest score in the pilot stage is the pretest value obtained by SD N 1 Danyang with the lowest value of 40, the highest value of 80 and the average value of 64,4 while the posteststage obtained with the lowest value of 56, the highest value 92 and the average value of 75,86. In addition, in the test phase, the 2 pretest values obtained by SD Negeri 4 Purwodadi with the lowest score of 52, the highest value of 88 , and the average value of 67,41 while the posteststage obtained with the lowest value of 60 , the highest value 96 , and the average value of 77,05 . In this broad trial stage, the average value of pretest and postestincrease, so it can be said that the existence of learning by using new teaching materials affect the value of students and also students experience the development in learning fairy tales.

\subsection{Pretest-Postest Experiments}

This experimental data analysis was conducted to compare pretest and postestof new teaching materials by using independent $t$ test. Independent $t$ tests are conducted to determine the importance of improving students' intensive reading skills by using new instructional materials. This significance is based on the results of pretest and postestscores on new teaching materials. Before the calculation of different test or t-test is done, test the data linearity as t-test prerequisite. Calculation of prerequisite test conducted in this research is morality test and homogeneity test. 


\subsubsection{Test of Experiment Group Normality}

Testing the normality of intensive reading skills in the experimental class by using new learning materials was calculated by SPSS Kolmogorov Smirnov, that the highest average was found in the postestgroup with an average yield of 83,6 and the lowest average was in the pretest group with average results 71,06667 . This implies that pretest and postest data are from normal distributed populations.

\subsubsection{Test of Control Group Normality}

The normality test for students' intensive reading skill of the control group by using the old teaching material was calculated by SPSS Kolmogorov Smirnov, that the highest average was found in the control group with an average of 78 and the lowest mean was in the control group with an average of 71,6. This implies that pretest and postest data are from normal distributed populations.

\subsubsection{Homogeneity Test Between Pretest Value of Control Group and Experiment Group}

Homogeneity test for students' intensive reading skill was calculated by SPSS Kolmogorov Smirnov, that it was found that sig. greater than $\alpha$ or sig $>0.05$. Data from the pretest value show Sig. $0,677>0,05$ thus that $\mathrm{H}_{0}$ is accepted. From the calculation, it is found that the data is homogeneous or the variance of the two homogeneous populations which means that the data is homogeneous or has the same variance.

\subsubsection{Homogeneity Test Between Postest Control Group and Experiment Group}

Homogeneity test for students' intensive reading skill was calculated by SPSS Kolmogorov Smirnov, that the result was sig. greater than $\alpha$ or sig $>0.05$. Data from the pretest value show Sig. 0,064> 0,05 thus that $\mathrm{H}_{0}$ is accepted. From the calculation, it is found that the data is homogeneous or the variance of the two homogeneous populations which means that the data is homogeneous or has the same variance.

\subsection{Independent T Test Analysis}

Based on this research was using Independent $T$ test, that is comparing two postest average with different treatment to unrelated samples. Independent $\mathrm{T}$ Test to compare two groups. Significant level $\alpha=$ 0,05. Statistical test analysis by comparing in two different classes to unrelated samples is using SPSS Kormogolov Smirnov application.

\subsubsection{Independent T Test Results}

Based on Table 1 can be seen the results of static analysis of t test Independent Sample Test by using SPSS Kormogolov Smirnov with hypothesis formulation that is $\mathrm{HO}=$ Learning by using the old teaching materials effectively improve learning outcomes, and $\mathrm{H} 1$ = Learning by using old teaching materials plus fairy tale insightful character values to improve intensive reading skills more effectively improve learning outcomes. Based on the above result that the value of Sig. (2-tailed) more $<\alpha$ that is $0,034<0,05$. Thus, that decision $\mathrm{H} 0=$ rejected which means that $\mathrm{H} 1=$ accepted or learning by using old 
teaching materials plus fairy tale material with character insight values to improve intensive reading skills more effectively improve learning outcomes.

Table 1 Average results of postest experiment group and control group

\begin{tabular}{llllll}
\hline No & Group & Average & Free Degree & Sig & Description \\
\hline 1. & Experiments & 83,6 & 30 & & \\
2. & Control & & 30 & &
\end{tabular}

Source: Results of Calculate Application SPSS Kolmogorov Smirnov

Based on figure 1 histogram mean score postest experimental group 83,6 and mean value of postest control group 78. Both group have difference of value 5,6. It identifies that the experimental group postest score is higher than the control group postest score with a difference of 5,6 and has significant differences. Finally, it can be concluded that the learning by using old teaching materials plus storytelling materials with character insight values to improve intensive reading skills more effectively improve the learning outcomes of third grade students of Elementary School in Purwodadi District of Grobogan Regency.

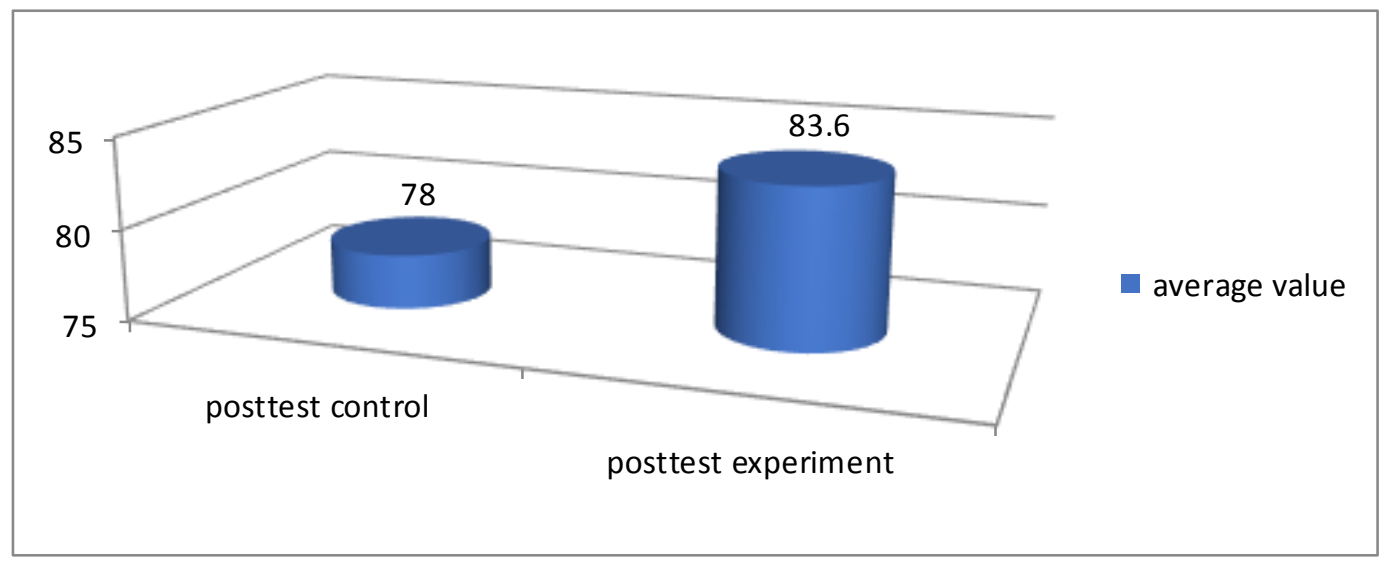

Fig. 1 Postest Histogram of Experiment Group and Control Group 


\section{Conclusion}

The need of teaching materials of teachers and students in reading fairy tales can be known through the findings of exploratory studies and literature studies, therefore teachers and students need a complete and easy to understand instructional material to achieve learning objectives. The results of observations and findings of teaching materials were then consulted with experts and revised.

Development of prototypes that have been compiled and validated and then revised for limited experiments. The result of experiment of teaching material is limited to fairy tale material with characteristic values to improve students' intensive reading skill in the $3 \mathrm{rd}$ semester of class III in SD Negeri 16 Purwodadi, Purwodadi Sub-district, GroboganRegency, from 10 students got the average value of 4,2. Scores according to the assessment guide (Sukardjo., 2009, p. 84) are included in the criteria very well.

Some experimental findings improved for extensive testing trials. The result of experiment is 1 , the pretest value obtained by SD N 1 Danyang with mean of 64,4 whereas in stage postest obtained the mean value 75,86. Beside that, at the broad trial stage 2 were pretest values obtained by SD Negeri 4 Purwodadi with the average value of 67,41 while in the postest stage were obtained with the mean value of 77,05 .

Independent $t$ test is done to know the effectiveness of teaching materials. The result of statistical analysis of t test Independent Sample Test by using SPSS Kormogolov Smirnov formula with hypothesis formulation is Sig value. (2-tailed) more $<\alpha$ that is $0,034<0,05$. Thus that decision $\mathrm{H}_{0}=$ rejected which means that $\mathrm{H}_{1}=$ accepted or learning by using old teaching materials plus fairy tale material with character insight values to improve intensive reading skills more effectively improve learning outcomes. The mean score of the experimental group postest 83,6 and the mean score of the control group postest 78. Both groups had a difference of 5,6. It identifies that the experimental group postest score is higher than the control group postest score with a difference of 5,6 and has significant differences. Finally, it can be concluded that the learning by using the old teaching materials plus storytelling materials with the insight of character values to improve the intensive reading skill more effectively improve the learning outcomes of third grade students of Elementary School in Purwodadi District of Grobogan Regency.

\section{Suggestions}

For more meaningful learning, suggestions to teachers need to: (a) have good preparation and planning for teaching; (b) provide and be able to use teaching materials that support the learning process; (c) presenting material that goes beyond simply presenting what is already contained in the teaching materials; (d) develop their professional skills to enhance students' intensive reading skills; and (e) engage in teaching material activities by integrating material with the character values contained in fairy tales.

Suggestion to third grade elementary students to use student's book in learning to read fairytale story because it has been proven and tested can: (1) improve students intensive reading skill in various ways; (2) motivating and enabling students in learning; (3) cultivate students' social awareness of the surrounding environment by applying the character values contained in fairy tales. Suggestions to the authors of the book to be able to use the book compiled so that learning becomes more interesting and meaningful for students.

Furthermore, to learners of the next Indonesian language, to be able to: (a) develop the skills of Inodnesia language and skills, especially the intensive reading skills of fairy tales with more creative and innovative; (b) developing and finding varied and interesting strategies, approaches, and models for 
learning Indonesian especially reading fairy tales; and (c) developing research in other Indonesian fields. Suggestion to the policy maker, that is the local government, especially the education office of Grobogan Regency, to be able to: (a) recommend that this instructional material is used in SD Purwodadi District of GroboganRegency because it has been tested effectiveness, and adjusted to the needs and condition of students; (b) provide a budget for the multiplication of teaching materials for students to have free primary school; (c) facilitating the facilities and infrastructure teachers need for the development of teaching materials; and (d) carry out professional teacher improvement activities.

\section{References}

Asma, Jamal Mamur. (2014). Buku Panduan Internalisasi Pendidikan Karakter di Sekolah Dasar. Yogyakarta: Diva Press.

Borg \& Gall. (2003). Education Research. New York: Allyn and Bacon.

Dalman. (2014). Keterampilan Membaca. Jakarta: Raja Grafindo Persada.

Daryanto. (2014). Pengembangan Perangkat Pembelajaran (Silabus, RPP, PHB, Bahan Ajar). Yogyakarta: Gava Media.

Febriani, Meina. (2012). Pengembangan Bahan Ajar Apresiasi Dongeng Banyumas bagi Siswa SD Kelas Rendah. Jurnal Pendidikan Bahasa dan Sastra, 1(6): 1-8.

Ibnoe. (2016). Mari Mendongeng. Yogyakarta: Zora Book.

Mardiah, dkk. (2016). Pengembangan Modul Membaca Intensif Materi Cerita Petualangan Berbasis Intensif. Jurnal Penelitian dan Pengembangan, 1(1): 1115-1119.

Mustari. (2014). Nilai karakter untuk Refleksi Pendidikan. Jakarta: Raja Grafindo Persada.

Samani dan Hariyanto. (2012). Konsep dan Model Pendidikan Karakter. Bandung: Rineka Cipta.

Sukardjo M. (2009). Landasan Pendidikan Konsep Dan Aplikasinya. Jakarta: Rajawali Pers.

Sukmadinata, Nana Syaodih. (2012). Metode Penelitian Pendidikan. Bandung: PT Remaja Rosdakarya.

Tarigan. (2008). Membaca sebagai suatu Keterampilan Berbahasa. Bandung: Angkasa.

Ulum, Wisda Miftakul. (2014). Pengembangan Pengembangan Buku Teks Membaca Intensif Berbasis Karakter di Sekolah Dasar. Junal Penidikan Humaniora, 2(2): 130-143.

\section{Copyrights}

Copyright for this article is retained by the author(s), with first publication rights granted to the journal.

This is an open-access article distributed under the terms and conditions of the Creative Commons Attribution license (http://creativecommons.org/licenses/by/4.0/). 